\title{
Perception and knowledge about oral health of caregivers of children with microcephaly
}

\author{
Percepção e conhecimento sobre saúde oral de cuidadores \\ de crianças com microcefalia
}

\author{
Andréa Rose de Albuquerque SARMENTO-OMENA ${ }^{1}$ iD 0000-0002-2602-0611 \\ Luciano Bairros da SILVA ${ }^{1}$ iD 0000-0002-8864-3881 \\ Ana Lídia Soares COTA ${ }^{1}$ iD 0000-0001-8220-7846 \\ Camila Maria Beder RIBEIRO1 iD 0000-0003-0203-3079
}

\section{ABSTRACT}

Objective: To understand the perception and knowledge of caregivers of children with microcephaly on oral health care. Methods: This is a qualitative study with a research-action method, in which semi-structured interviews - diagnostic and evaluative - and oral health workshop were adopted as techniques for data collection and intervention. The study was conducted in a group aimed at caregivers of children with microcephaly, offered in the public health network of the capital Maceió, Alagoas. Nine women caring for children with microcephaly participated in the study. The participants' statements were transcribed and, through the thematic analysis, the data was categorized and discussed. Results: The main caregivers of children with microcephaly were mothers and grandmothers. Of these, $45 \%$ had incomplete secondary education. Most reported self-care with their impaired oral health, were unaware of the risk of transmission of dental caries-related bacteria, did not offer exclusive breastfeeding until 6 months of age, and offered artificial milk to the children with sugared and farinaceous milk. Conclusion: For caregivers of children with microcephaly, oral health care is a less valuable topic when compared to other demands, both at home and other physical treatments. Responsibility for care is aimed at the maternal figures, which makes it difficult for them to take care of their own oral health. Educational action on oral health minimized doubts and fragilities for the self-care and care of children related to oral health.

Index terms: Disabled person. Microcephaly. Oral health.

\section{RESUMO}

Objetivo: Compreender a percepção e o conhecimento das cuidadoras de crianças com microcefalia sobre cuidados de saúde bucal. Métodos: Trata-se de um estudo qualitativo, com método pesquisa-ação, no qual se adotou como técnicas para coleta de dados e intervenção as entrevistas semiestruturadas - diagnóstica e avaliativa - e oficina de saúde bucal. O estudo foi realizado em um grupo destinado a cuidadoras de crianças com microcefalia, ofertado na rede pública de saúde da capital Maceió, Alagoas. Participaram da pesquisa nove mulheres que cuidam de crianças com microcefalia. As falas das participantes foram transcritas e, por meio da análise temática, realizou-se a categorização e discussão dos dados. Resultados: As principais cuidadoras das crianças com microcefalia

$\boldsymbol{\nabla} \boldsymbol{\nabla} \nabla$

${ }^{1}$ Centro Universitário CESMAC. Rua Cônego Machado, 918, Farol, 57051-160, Maceió, AL, Brasil. Correspondência para / Correspondence to: ARA SARMENTO-OMENA. E-mail: <andrea@clinicaguri.com.br>.

$\boldsymbol{\nabla} \mathbf{v}$

How to cite this article

Sarmento-Omena ARA, Silva LB, Cota ALS, Ribeiro CMB. Perception and knowledge about oral health of caregivers of children with microcephaly. RGO, Rev Gaúch Odontol. 2019;67:e20190044. http://dx.doi.org/10.1590/1981-86372019000443594 
foram as mães e as avós. Destas, $45 \%$ possuíam ensino médio incompleto. A maioria relatou um autocuidado com sua saúde bucal prejudicado, desconheciam o risco de transmissão das bactérias relacionadas à cárie dentária, não ofereceram aleitamento materno exclusivo até os 6 meses de idade e ofertaram às crianças leite artificial engrossado com farináceos e com açúcar. Conclusão: Para as cuidadoras de crianças com microcefalia a atenção à saúde bucal é um tema de menor valor se comparado outras demandas, tanto domiciliares, como a outros tratamentos de ordem física. A responsabilização pelo cuidado está destina às figuras maternas, o que as dificultam de realizar o cuidado da própria saúde bucal. Ação educativa sobre saúde bucal minimizou dúvidas e fragilidades para o autocuidado e ao cuidado das crianças relacionados à saúde bucal.

Termos de indexação: Saúde bucal. Microcefalia. Pessoa com deficiência.

\section{INTRODUCTION}

Microcephaly is characterized by the measuring of the skull using technique and standard equipment, in which the Cephalic Perimeter (CP) presents a measurement of less than two (-2) standard deviations below the specific average for sex and gestational age [1]. Such pathology may result from congenital anomalies: changes in structure or function of the body that are present at birth and are of prenatal or postnatal origin. It may be accompanied by epilepsy, cerebral palsy, retarded cognitive development, motor, speech, and visual and auditory deficiency [2].

Reports on the increase in microcephaly cases in the Northeast region of Brazil in 2015 made the scientific community suspect of the relationship between maternal infection by the Zika Virus and malformations in the Central Nervous System of the newborn. It is important to note that in addition to microcephaly, other perinatal complications may be associated with congenital Zika virus infection, such as optic nerve hypoplasia, myopia and hyperopia, and funduscopic alterations [3].

In this context, the health care system has a great challenge to understand the teratogenic effect of the virus and to elaborate intervention with the objective of improving the cognitive-behavioral development of these children, aiming at the best care of children and their families [2].

The demand for the care of children with specific health needs, such as microcephaly, promotes their caregivers' physical and mental wear out. Therefore, they need to feel welcomed, guided and motivated so that they can contribute effectively to the health of their children [4]. Poor oral hygiene conditions have been considered one of the major oral health problems in patients with some type of deficiency, and although caregivers present positive attitudes related to oral health, the results observed in previous studies indicate that their knowledge is limited [5].
Understanding and being aware that oral health is related to systemic health is fundamental for all health professionals. Therefore, it is important to emphasize the prevention of diseases, such as dental caries, with changes in habits and attitudes [6].

Thus, the present study has questioned whether the persons responsible for the care of children with microcephaly have adequate knowledge to perform the oral hygiene of the children under their care? To answer this question, this research aimed to understand the perception and knowledge of caregivers of children with microcephaly on oral health care, and it was also sought to identify difficulties for this care and guide them on the knowledge and practices in health care.

\section{METHODS}

The present study is in accordance with resolution 466/12, opinion approved by the Brazil Platform, with CAAE: 61304316.8 .0000 .0039 and voucher number: $110586 / 2016$, on $12 / 07$ th/2016.

It is a qualitative study, with a research-action method, in which semi-structured interviews and oral health workshop were adopted as techniques for data collection and intervention.

The research field was a group intended for the participation of caregivers of children with microcephaly, as well as for these same children, offered by the public health network of the capital Maceió, Alagoas. This group was originated after the publication by the Ministry of Health of Ordinance No. 1813, dated November 11th, 2015 , created after changes in the epidemiological pattern of microcephaly occurrences, increase of cases and unusual clinical pattern, characterized at the time as emergence in public health.

The group was coordinated by a multiprofessional team of the municipal health network and included the 
technical areas responsible for the health care of the child, the disabled person and the primary care management. The main purpose of the group was to accompany families and children born from October 2015, wherever there was suspicion of or confirmation of the diagnosis of microcephaly. The meetings with the group of caregivers of children with microcephaly began in April 2016. The meetings were monthly, with an average duration of three hours, where both the anxieties of the family members and the professional conduct for the participants' quality of life were discussed.

It should be noted that the children with microcephaly that are part of the group were diagnosed during the period when Brazil was in the emergency state of microcephaly related to the Zika virus. However, until the conclusion of the present study, there was no serological confirmation of the cases by the responsible institutions.

All participants in the group, aged 18 years or older, were invited to participate in the study. Of these, nine (9) women accepted to participate in all phases of the research, and they signed the Informed Consent Term (TCLE). In order to preserve the anonymity of the participants, their names were replaced by species of trees from the Brazilian Northeast.

In the first phase of the research, semi-structured interviews were carried out, individually, with the caregivers who were part of the group. A script was used to perform an initial diagnosis of the perception and knowledge of the caregiver on oral health, divided in part " $\mathrm{A}$ " when addressing questions to the caregiver about their care with their own oral health and part " $\mathrm{B}$ " related questions related to the care provided by caregivers for their children with microcephaly, the diagnostic interview. The speeches were collected with the aid of a recorder and transcribed in full by a single researcher, previously trained.

The second phase of the survey occurred one month after the diagnostic interview. With the proposal to carry out an educational action, a professional dental surgeon, with training and experience in pediatric dentistry, coordinated one of the meetings of the group of caregivers of children with microcephaly. The moment was organized in the form of a theoretical-practical workshop where the topics on oral health of the caregivers and the oral hygiene of their children with Microcephaly were discussed. Dialogic exchange had as objectives the prevention and promotion of the oral health of the dyad, demystifying fears and taboos, as well as doubts and guiding the caregivers to feel able to adequately perform oral hygiene of children with microcephaly. Scientific knowledge, popular knowledge and practical experience of the caregivers were the tools used to produce the workshop.

The third phase occurred eight months after the workshop described previously was performed. The questionnaire used in the diagnostic interview was again applied in order to evaluate the acquisition of knowledge and / or behavior change in the daily care of the caregiver as well as with the child with microcephaly, the evaluative interview.

Through the thematic analysis, the categorization and discussion of the collected content was carried out. Themes were defined for the data analysis process, in which patterns of meaning and potential interest for the research were identified; however, this division is merely didactic, since the themes intertwine and dialogue with each other: Oral Health; Self-care; Access to the dentist; Breastfeeding and Suctioning Habits of Children; Oral Hygiene of Children; Chronology of Child Dentition.

\section{RESULTS}

The results of the diagnostic and evaluative interviews, related to closed questions, are presented below (tables 1 and 2).

Speeches taken from the caregivers, based on the open questions used for the semi-structured interviews and during the workshop on oral health, were worked with the thematic analysis method and are presented as follows:

\section{Oral health}

In the item of self-perception about the caregiver's oral health, the good and excellent answers were classified as positive self-perception; and the poor response, as negative self-perception. Most caregivers report positive self-perception regarding their oral health, however, the most reported reasons for consulting the dentist were for curative or aesthetic care.

\section{Self care}

It was observed in the present research that caregivers present overload of care with their children, 
Table 1. Interview Results - part A.

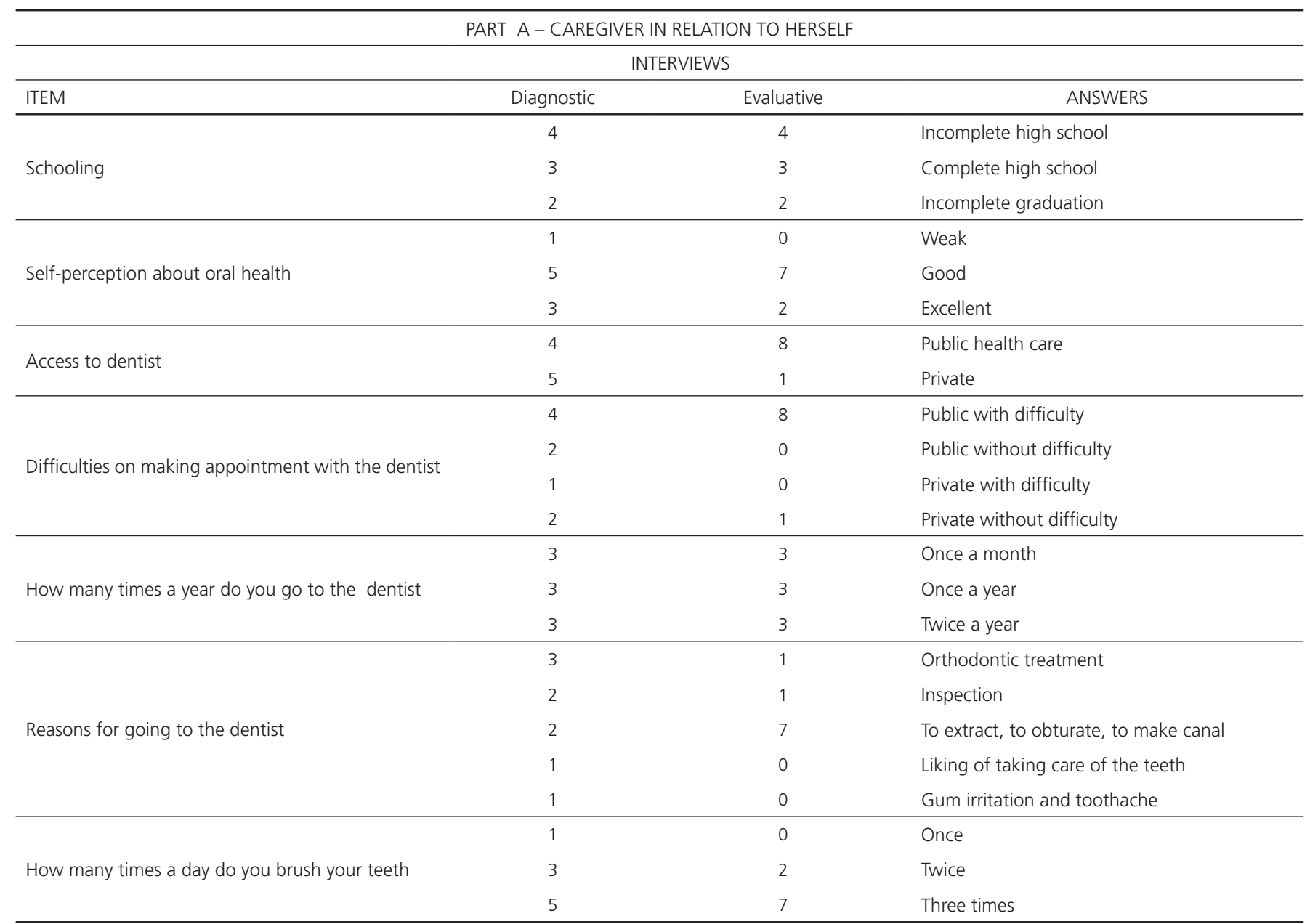

Source: Prepared by the authors. Maceió/AL - 2017.

and that this may justify the damage to their self-care. It was reported in the evaluative interview that there was an increase in the brushing frequency of the caregivers after the oral health workshop, however, the demands for child care only increased.

Likewise, it was evident that caregivers presented poorly adapted behaviour regarding the demand for care given to their children with Microcephaly and their own needs for self-care.

"The health of my mouth is very weak [...]. After I had the baby I have slept without brushing my teeth. [...] there is so much to do that we get lost". (Aroeira).

"I do brushing, I'm conscious, twice a day, I wish I could do it but more than this, but I do not have the time". (Jaqueira).

"I brush twice a day on average, I use toothpaste and mouthwash and I use dental floss, but I am not going to lie, I do not use it often, the right thing would be to use it after every meal, I use dental floss, but it is not frequent. [...] I really want to put it in the Padovan method [...], he will also start visual stimulation because he has got visual and auditory problems too, all on Zika's account". (Algaroba)

"I brush my teeth three times a day, but I do not use dental floss". (Oiticica).

"... after I had my child ... I have not been able to go to the gynaecologist, dentist ... this is going to have been 1 year and 9 months ... the difficulty is great to get a consultation with the SUS (Public Health care) appointment system. You need to be more careful with the people who are caregivers too [...]" (Jaboticabeira).

"What consumes us a lot is both physical and psychological rush. Because people who deal with these children always receive lots of news that are not motivating about the baby's diagnosis" (Pitombeira). 
Table 2. Interview results - part B.

\begin{tabular}{|c|c|c|c|}
\hline ITEM & \multicolumn{2}{|c|}{ INTEREVIEWS } & ANSWERS \\
\hline \multirow{2}{*}{ Degree of kinship } & 7 & 7 & Monthers \\
\hline & 2 & 2 & Grandmothers \\
\hline Number of teeth & 0 a 7 & 2 a 16 & Teeth \\
\hline \multirow{3}{*}{ When was the oral hygiene started } & 9 & 9 & Since birth \\
\hline & 0 & 0 & When using liquid foods \\
\hline & 0 & 0 & When the first teeth appear \\
\hline \multirow[t]{3}{*}{ What do you use to do the baby's oral hygiene } & 2 & 1 & Baby finger tooth brush \\
\hline & 1 & 8 & Tooth paste \\
\hline & 1 & 7 & Little tooth brush \\
\hline \multirow[b]{2}{*}{ How many children with teeth and how many without tee } & 6 & 0 & Without teeth \\
\hline & 3 & 9 & With teeth \\
\hline \multirow{4}{*}{ What are the difficulties to perform oral hygiene } & 3 & 1 & Curb the mouth \\
\hline & 1 & 1 & Bite \\
\hline & 1 & 0 & Reflux \\
\hline & 4 & 7 & Without difficulty \\
\hline
\end{tabular}

Source: Performed by the authors. Maceió (AL), 2017.

\section{Access to the dentist}

The most frequent difficulties presented by the caregivers in the public health services were related to the appointment of consultations, lack of materials and equipment breakdown; and in the private services, to vacancies in the professionals' agenda.

"I have a lot of difficulty going to the dentist because I use the Public Health Care Service, when we are able to have an appointment, then when I get there and the chair is broken, some clinical material is missing, [...] then we arrange another day and it never works out, and so it goes, it's like this!" (Jaboticabeira).

"I have difficulty because there is a dentist at the public post near where I live and despite the goodwill of the health agent, some people must finish the treatment first so that others can start theirs". (Aroeira)

"I go to the dentist through the Public Health Care Service (SUS), I have no difficulty in going, I always manage to arrange an appointment, I go to the dentist when I feel some pain or when there is a hole, then I go". (Cajazeira)

"... I had a private health plan for the dentist, but not anymore nowadays, nowadays I use the public health care service, I have no difficulty in going to the dentist because there is a public post near my house". (Oiticica).

"I need a dentist, a gynaecologist ... the people who take care of these children need an orthopaedist because they have to carry them a lot ... I feel pain in the back". (Aceroleira) 
"I cannot get a dentist for me, I have my wisdom tooth aching every day". (Ingazeira)

"I can not take care of myself, it's 24 hours with this child ... The workshop was very good because I learned how to take care of his hygiene, but as I said, I can not go out to arrange an appointment so it's very difficult to get a dentist for me ..." (Aroeira)

\section{Breastfeeding and suctioning habits of children with microcephaly}

It was verified, in this study, that children with microcephaly were not exclusively breastfed for the recommended period of six months.

"My son sucked only at the beginning". (Cajazeira)

"Mine has sucked up to now, bottle and breast". (Jaboticabeira)

"He sucked until I ran out of milk, after three months breastfeeding, but if I had had milk he would have continued then". (Algaroba)

In this study, caregivers introduced the pacifier because their babies cried a lot and were irritated, but in the following reports they say the use is restricted. The oral phase is the stage of development in which the child takes pleasure in the oral region: lips, tongue and teeth. The world is perceived through contact with the mouth.

"I have a question about the pacifier, I have heard a lot of people say that pacifiers impair the formation of the teeth and cause the children to become toothy, is it true?" (Carambola)

"My daughter only uses the pacifier to sleep" (Aroeira) (Jurema)

"Mine has been using it since she was a little girl"

"She has been using it since she was young, I think that's why she stopped breastfeeding at 2 months" (Pitombeira)

"He/she uses it very rarely, only when she/he cries". (Imbiriba)

Caregivers reported resistance to introducing solid foods due to the child's difficulty in swallowing, gastricoesophageal reflux and non-acceptance of the child for new foods. The food most offered to children with microcephaly was milk thickened with industrialized flours and "little sugar".

"[...] sugar is not only in the milk, in the tea and neither in the juice in any way? Mine does not even drink the tea without sugar, the first time I gave it, she did not take it without sugar, no way, I put a little sugar there and then she had it all. Now we avoid sugar in the juice". (Carambola)

"[...] I've tried to give him only milk, but the milk does not support him. When he drinks pure milk he throws it all up, and when he has something that has been thickened then he gladly takes it and does not vomit. There was a time when he was gushing out a lot, but now it's getting less and less, I was even scared". (Cajazeira)

\section{Oral hygiene of children with microcephaly}

During the diagnostic interviews, it was evident that caregivers who received oral hygiene guidelines before discharge from the maternity ward performed procedures in an assertive way. A very positive result detected in the evaluative interviews was the report of the adequate use of fluoride toothpaste and age-appropriate toothbrush.

"I'm sure it's necessary to clean the baby's mouth when they suck, she was hospitalized for 12 days and they taught her how to clean the baby there, they taught me that I could get a clean diaper wet it and pass it around her little mouth and so also when she gushes out, right! Her first tooth appeared when she was four months old. I'm always doing oral hygiene, when she throws up and she likes it, she laughs". (Aroeira)

"Surely the child needs oral hygiene, I have been cleaning his little tongue with rosy honey or water since he was very young. The first dentin began cutting the gum out from yesterday to today, [at this moment she shows the baby's gums]. I do the oral hygiene once a day, only in the morning, I use a little cloth and I have a baby finger brush, he likes it, he stays quiet when I clean him, he sucks my finger". (Jaboticabeira)

"His oral hygiene ... I'm not going to lie, I used to do, but now, he's got his little teeth and when I'm going to do it, he bites me [laughs]. The first teeth appeared at 10 months. When I did the hygiene I used rosé honey and a wet diaper". (Cajazeira)

"I clean his mouth with Salsep, when I feed him with his baby bottle, I clean it like that, as the speech 
therapist taught, she told me to get a gauze and clean him because that helps to prevent cold sore, I do not do it every day because he has reflux, I clean him then I give him his baby bottle, but I clean him every other two days, not every day, I think it bothers him. He lets you do the cleaning, He does not cry, no". (Oiticica)

"I already take care of the oral hygiene, I clean with a little cloth and I have already got a brush to stimulate, I do not use toothpaste, I do not have any difficulty in accomplishing this hygiene, it is tranquil, she likes it". (Pitangueira)

"I do her oral hygiene, I clean her tongue with a wet little diaper, I do this cleaning once, twice a day, the difficulty I have is that she bites, when I try to do it she bites me, she locks her mouth, but she still has no teeth". (Caramboleira)

"I think he needs oral hygiene from birth, I usually do it once a day, because of his tongue because his tongue turns white and because he too has a lot of sensitivity, when he puts the bottle tip, he wants to regurgitate, the Speech therapist passed stimuli with gauze, a glove, passing the finger for him to know, for him to feel. He has not yet gone to the dentist and has no teeth". (Algaroba)

"I do her mouth's hygiene as I was taught, I put very little toothpaste, just brush the brush. She lets me do it, I do it twice a day". (Ingazeira)

"She has got the front teeth, but she has got a swollen gum ... I do it with a toothpaste, but now I'm doing it with a little diaper because she's sick and the brush seems to be uncomfortable now" (Aroeira)

"I always charge this [referring to oral hygiene], my husband and I sanitize my son's mouth very well. I use toothpaste with fluoride and a little brush. Some mothers are still surprised and ask: do you use toothpaste with fluoride?" (Aroeira)

\section{Chronology of dentition of children with microcephaly}

Some symptoms were associated with the eruption of the teeth of children with microcephaly, the most frequent being increased salivation and irritation of the baby. The delay in eruption of the first tooth was a concern in $50 \%$ of the caregivers of this study, since their children did not present teeth with the age even at 12 months of age.

\section{DISCUSSION}

The oral health of patients with specific needs in Brazil is very precarious. Studies show that parents with little knowledge have less care regarding the oral health of their children [7].

The research revealed that in the family, the mother is one of the people who most lives with the child with specific needs, having a primary role in the health and dynamics of dental care, being decisive in the success of treatment and in the prevention of oral diseases. It is interesting to introduce oral hygiene concepts in oral health programs, because of the importance of educating the family from the mother [8].

Faced with this role, in addition to all the others developed by the mother, the overload on one family member is evident - most often, the mother - in the care given to children with specific needs due to the complexity of this daily practice.

The support of a stable and well-established social network is recommended, so that caregivers share learning and thus facilitate their adaptation to the health situations experienced by their children [9]. The inclusion of other family members in the decisions of the therapeutic plans with the multidisciplinary team will favor and encourage the sharing of responsibility for care in the management of the child. However, because of the scarcity of activities for children with specific needs, the need for training for professionals and the creation of public policies for these children and their families is evident in basic care services [10].

The caregivers' self-perception on oral health is a matter of subjective nature. Feeling healthy or ill is mediated by factors of psychological, social and cultural nature, without relation to the individual's clinical situation [11].

Although SUS (Public Health Service) incorporates the dental surgeon, it is observed that the access and reception of the health services for the population that needs this professional is still precarious. The desired change to improve access includes: investment, professional training, recognition of the specialists in primary care, implementation of continuing educational programs, provision of procedures and the development of more effective and lasting oral health practices [12].

Research has shown that most children with Microcephaly have not been breastfed. Similarly, the 
infants between 0 and 23 months studied by Monteschio et al presented inadequate food intake, since weaning and the introduction of complementary feeding occurred early [13].

Breastfeeding favors the development of the stomatognathic system and prevents the appearance of bad oral habits which, in turn, can lead to dental malocclusions. Breastfeeding requires intense muscular labor of the newborn, promoting suction, swallowing and breathing, stimulating the development of the face and its attachments. The psychological, social, cultural and biological factors have also to be considered and these are present in the child's life, as well as the genetic predisposition to changes in the stomatognathic system. It is up to the dental professional to indicate all the benefits that this action brings to the development of the oral, nutritional, immunological, affective and psychological functions of the baby [14]. The benefits of breastfeeding are clearly based on scientific evidence, but there are many factors involved in the success of the practice. There are no ideal and specific resources for the oral hygiene of people with disabilities, but professionals must have knowledge so that they can help the caregiver, as well as the patient, to improve their hygiene, adapting and respecting the particularities of each condition [15]. The use of fluoride dentifrice is safe for acute fluoride toxicity; however, it is a risk factor for dental fluorosis [16].

Dental eruption is a physiological phenomenon and the eruption of the first deciduous teeth occurs between 4 and 10 months of age, and the dentition is complete at around 30 months [17]. There is no scientific evidence between the relation of deciduous eruption to local and systemic manifestations yet. Some authors believe that the deciduous eruption is a physiological process unrelated to local or systemic manifestations, while other researchers believe in this relation. The most frequently mentioned symptoms are: irritability, increased salivation, local irritation, inflammation of the gums, restless sleep, fever, reduced appetite and diarrhea [18].

\section{CONCLUSION}

Oral health care is considered by people who care for children with Microcephaly as a less valuable issue when compared to the daily care demands that these children need both at home and with other physical treatments. It was also identified that the responsibility for the care of these children is destined to the maternal figures, which, together with other daily demands, make them difficult to perform the care of their own oral health. It was also evaluated that after educational action on oral health with the participants, doubts and fragilities for self-care and care of children related to oral health were minimized, making caregivers safer.

Although the Ministry of Health has withdrawn, in 2017, the emergency situation of cases of Microcephaly by the Zika virus, children with this diagnosis will need specialized care throughout their lives, requiring effective actions of health professionals both for children, as well as for those responsible for them. Regarding this, it is suggested that educational actions on oral health care be carried out; the co-responsibility of the different members of the family in the construction of therapeutic projects and in the care of these children; and guidance related to the benefits of breastfeeding for the health of children with specific needs.

\section{Collaborators}

ARA SARMENTO-OMENA participated in the design of the study design, the interviews, the oral health workshop and the article writing. LB SILVA contributed to the design of the study, data interpretation, article writing and carried out the revision of the final article. ALS COTA led the workshop on oral health and a critical analysis of important intellectual content. CMB RIBEIRO participated in the design of the study design and reviewed the final article.

\section{REFERENCES}

1. Brasil. Ministério da Saúde. Protocolo de vigilância e resposta à ocorrência de microcefalia e/ou alterações do sistema nervoso central (SNC). 2016.

2. Brunoni D, Blascovi-Assis SM, Osório AAS, Seabra AG, Amato $\mathrm{CAH}$, Teixeira MCTV, et al. Microcefalia e outras manifestações relacionadas ao vírus Zika: impacto nas crianças, nas famílias e nas equipes de saúde. Ciência e Saúde Coletiva. 2016;21(10):3297-302.

3. Salge AKM, Sousa TC, Souza MC, Souza RRG, Minamisava R, Souza SMB. Infecção pelo vírus Zika na gestação e microcefalia em recém-nascidos: revisão integrativa de literatura Ana. Rev Eletr Enf. [periódico na Internet]. 2016 Mar [acesso 2017 Fev 3]. Disponível em: <https://revistas.ufg.br/fen/article/view/3 9888>.

4. Paixão ES, Barreto F, Da Glória Teixeira M, Da Conceição N, Costa M, Rodrigues LC. History, epidemiology, and clinical 
manifestations of Zika: a systematic review. Am J Public Health. 2016;106(4):606-12. http://dx.doi.org/10.2105/AJPH. 2016.303112

5. Coelho BB, Osório S dos RG. Atendimento Odontologico para Crianças Portadoras de Deficiencia Visual. Braz J Surg Clin Res. 8(2):47-50.

6. Beatriz C, Sales Cunha C, De Aguiar Ribeiro A, Cruxên B, Volschan G. Seria a cárie dental uma doença transmissível? J Bras Odontopediatr Odontol Bebê. 2003;6(30):107-10.

7. Sousa IF, Ferreira DL, Neto josé machado M. Sensibilização de pais de crianças com necessidades especiais. Gestão e Saúde [Internet]. 2014 [cited 2016 Jul 17];5(4):pag. 23532368. Available from: http://gestaoesaude.unb.br/index.php/ gestaoesaude/article/view/989

8. Marcelino G, Parrilha VA. Educação em saúde bucal para mães de crianças especiais um espaço para a prática dos profissionais de enfermagem. Cogitare Enferm. 2007;12(1):37-43.

9. Coelho BB, Osório SRG. Atendimento Odontologico para crianças portadoras de deficiência visual. Braz J Surg Clin Res. 2014;8(2):47-50.

10. Delalibera M, Presa J, Barbosa A, Leal I. Sobrecarga no cuidar e suas repercussões nos cuidadores de pacientes em fim de vida: revisão sistemática da literatura. Ciênc Saúde Coletiva. 2015;20(9):2731-2747. http://dx.doi.org/10.1590/141381232015209.09562014

11. Alvarenga FAS, Henriques C, Takatsui F, Montandon AAB, Telarolli Junior R, Monteiro ALCC, et al. Impacto da saúde bucal na qualidade de vida de pacientes maiores de 50 anos de duas instituições públicas do município de Araraquara-SP, Brasil. Rev Odontol Unesp. 2011;40(3):118-24.
12. Manassero FB, Bavaresco CS. Inserção do Cirurgião-dentista na estratégia de saúde da família: revisão de literatura. Rev APS. 2016;19(2):286-91.

13. Monteschio CAC, Gaíva MAM, Moreira MD de sousa. O enfermeiro frente ao desmame precoce na consulta de enfermagem à criança. Rev Bras Enferm. 2014;68(5):869-75. http://dx.doi.org/10.1590/0034-7167.2015680515i

14. Casagrande L, Vargas Ferreira F, Hahn D, Taís Unfer D, Rodrigues Praetzel J. Aleitamento natural e artificial e o desenvolvimento do sistema estomatogmático. Rev Fac Odontol Porto Alegre. 2008;49(2):11-7

15. Hartwig AD, Junior IFS, Stumier VM, Shardosim LR, Azevedo MS. Recursos e técnicas para a higiene bucal de pacientes com necessidades especiais. Rev ACBO. 2015;4(53):1.

16. Cury JA, Maria L, Tenuta A. Riscos do uso do dentifrício fluoretado na prevenção e controle de cárie na primeira infância. Rev Fac Odontol Porto Alegre. 2012;53(3):21-7.

17. Ferreira FV, Machado MVS, Ardenghi TM, Praetzel JR. Manifestações sistêmicas e/ou locais associadas à erupção dos dentes decíduos: estudo retrospectivo. Pesq Bras Odontoped Clin Integr. 2009;9(2):235239.

18. Fabiana C, De Rezende M, Kuhn E. Percepção das Mães e pediatras de ponta grossa/pr em relação às alterações ocorridas em bebês durante a erupção da dentição decídua. Pesq Bras Odontoped Clin Integr. 2010;10(2):163-7.

Received on: $20 / 7 / 2018$ Final version resubmitted on: 30/11/2018 Approved on: 11/2/2019 